\title{
MODERN MECHANISM OF STRENGTHENING INNOVATIVE ACTIVITY OF TRANSPORT ENTERPRISES
}

\author{
Valentyn Halunko ${ }^{1}$ \\ Research Institute of Public Law, Ukraine \\ Iurii Chyzhmar² \\ Open International University of Human Development "Ukraine", Ukraine \\ Kseniia Kurkova ${ }^{3}$ \\ Institute of Public Law, Ukraine
}

\begin{abstract}
In order to create a well-functioning mechanism for the operation of the transport complex of the national economy of Ukraine and to increase the competitiveness of domestic transport in the world transport markets, a number of problems facing transport enterprises and the transport infrastructure of Ukraine in general need to be solved. The main issues are: a low level of service, non-compliance of the technical and technological level of domestic transport with European requirements, lagging development of transport services technologies, unsatisfactory level of transportation safety, a significant environmental load of transport to the environment, etc. The International Transport Corridor is a complex of land and water traffic arteries with appropriate infrastructure in a particular direction, including auxiliary structures, access roads, border crossings, service points, cargo and passenger terminals, equipment for traffic management, organizational and technical measures, legislative and regulatory acts that ensure the carriage of goods and passengers at the level corresponding to the requirements of the European Community. ITC №№ $3,5,7,9$ pass the territory of Ukraine and have a priority development in the national transport network. Relevant innovations that should support the transport industry and improve the service of providing transport services are as follows: electronic freight technology and single-window technology as a factor of acceleration of cargo movement; introduction of electronic document flow in logistics and transport activities (e.g., implementation of projects of electronic submission of information, electronic booking of queues, electronic declaration); development and implementation of standards for electronic document flow; methods of management and control over transportation costs in order to reduce the cost of delivery of goods by vehicles; application of cloud technologies and mobile devices; management of delivery terms; creation of new supply chains/transport corridors and multimodal formats, etc. The advantage of electronic document flow is that this system allows quickly sharing information. This is the implementation of single-window principle in transport terminals, where the most labour-intensive processes are associated with the processing of documents - both on arrival of cargo and on shipment. Therefore, it provides an opportunity to accelerate the time to handle a fairly large amount of information, multimodality - the possibility to transfer information from one mode of transport to another and make decisions at the junctions of transport modes. To date, the UIS has been used in the most developed ports, airports, and other intensive border crossing points in the world, attempts have been made to use it in Odesa, Illichivsk, "Yuzhnyi", and Bilhorod-Dnistrovskyi ports. For developing the mentioned structural transformations, we propose to introduce an improved organizational-economic mechanism of regulation of innovative activity. The proposed structure should have inherent functions related to the state innovation and investment policy in the transport and road complex, which will allow ensuring the effectiveness of the organizational-economic mechanism for regulating the innovation activity of transport enterprises.
\end{abstract}

Key words: transport enterprises, international transport corridors, innovative activity, Single Window, UIS European Association, organizational-economic mechanism, mechanism improvement.

JEL Classification: R41, R42, O32, G140

\footnotetext{
Corresponding author:

${ }^{1}$ Research Institute of Public Law.

E-mail: halunkov@i.ua

${ }^{2}$ Open International University of Human Development "Ukraine”.

E-mail: urijchizmar1974@mail.com

ORCID: http://orcid.org/0000-0002-4870-562X

${ }^{3}$ Department of Scientific and Legal Expertise and Legislative Work of Research, Institute of Public Law.

E-mail: kurkovaksena@ukr.net
} 


\section{Introduction}

The globalization of the world economy causes the intensification of inter-state economic ties, many times increasing the role of transport. From a geographic perspective, efficient transportation contributes to aligning regional disparities between countries and at the level of the Trans-European Transport Network (TEN-T). This allows considering the transport system as an important factor in economic growth, creating competitive advantages for national economies within the framework of the world economy, which is especially important given the integration of transport markets in Europe and the intensification of trade between the EU and Ukraine.

The characteristic features of the current state of the transport industry in Ukraine are the critical level of financial condition and the practically worn rolling stock and material and technical base. One of the ways of the indicated problems is the promotion of innovative activity of transport enterprises by the state, which will positively influence the progressive development of the transport system of Ukraine. To achieve this goal, authorities and business representatives are discussing existing differences and ways to eliminate them, attracting investors to innovative projects. An example of such cooperation is the conference "Transport and Logistics Innovation" on 10.10.2013, organized by the Ministry of Infrastructure of Ukraine, the Ukrainian Logistics Alliance, Logisticpoint, the state enterprise "Premier Expo", and led to the introduction of an electronic document flow system for key actors of transport infrastructure (Materialy konferentsiyi, 2013).

The purpose of the article is to consider theoretical and practical provisions of development of innovative mechanisms of activities of transport enterprises at the state and interstate levels.

\section{The methodology of research}

Technical and technological lagging in the level of transport development in Ukraine hamper the economic development of the country, its European integration, leads to unsatisfactory level of transport services, reduction of speed of goods promotion, dependence of foreign trade of Ukraine on foreign transport, loss of competitiveness of domestic transport, growth of danger and ecological load.

The main causes of these problems are (Prokopenko, 2012):

- insufficient financing of state transport development programs;

- insufficient volume of the attraction of foreign and domestic investments in transport development;

- imperfect taxation system;

- imperfection of the regulatory framework, slow harmonization of domestic transport legislation to the international one;
- intensification of the competitive struggle for transit flows in the context of the European Union's approach to the borders of Ukraine, etc.

The introduction of advanced transport technologies aimed at ensuring competitiveness in the market for transport services involves increasing the competitiveness of transportation on the basis of transport logistics. This allows coordinating the movement of material, informational, and financial flows on the "door-to-door" and "just-in-time - JIS" principles that will increase the quality of the provided transport services, which include the transportation of goods from the supplier to the consumer, will improve the service of cargo handling services. To do this, it is necessary to create interconnected logistical centres, promote the development and wide use of container transportation, conduct mixed (intermodal, multimodal) transportation and interaction of different modes of transport in transport nodes, the introduction of modern information technology for data exchange, transport documentation, electronic document flow.

\subsection{International transport corridors}

The development of the transport system is impossible without the realization of the transit potential of Ukraine. According to the British Institute of Rendall, Ukraine has the highest transport transit rating of 3.11 in Europe (Postanova Kabinetu Ministriv Ukrayiny, 2016). The transit rating of the territory of one or another country takes into account the development of transport systems and networks in it, as well as the level and state of the infrastructure. Implementation of transit capacities in Ukraine requires the development of a national transport network, which involves the development of main routes, which concentrate the largest transport flows and systems of international transport corridors (ITC) with the corresponding infrastructure. This is the most important direction of development of the transport-road complex in the innovation sphere. The development of international transport corridors is one of the conditions for Ukraine's integration into the EU, as well as its establishment as a transit state.

International transport corridor is a complex of land and water traffic arteries with appropriate infrastructure in a particular direction, including auxiliary structures, access roads, border crossings, service points, cargo and passenger terminals, equipment for traffic management, organizational and technical measures, legislative and regulatory acts that provide the carriage of goods and passengers at the level corresponding to the requirements of the European Community. ITC provides for the presence of automobile, railway, and water transport modes, operating near each other or as a band-wide in the tens or even hundreds of kilometres but oriented in one direction.

Creation of modern international transport corridors will allow connecting individual cities or settlements within 
several countries. For this, it is necessary to introduce innovative technologies for the movement of passengers and cargo between regions of European and other continents. Four strategic directions have been developed:

I. Central Europe - CIS countries;

II. Southern Europe, the Near East, Africa - CIS countries;

III. Scandinavia, the Baltics - the Near East, Transcaucasia, Central Asia;

IV. Northern Europe - Middle Asia, China, the Far East.

ITC №№ 3, 5, 7, 9 pass the territory of Ukraine and have a priority development in the national transport network (Table 1) (Sereda, 2012).

In addition, Ukraine initiated the creation of a new Baltic Sea - Black Sea ITC and proposed to include Illichivsk-Poti ferry crossing in the Europe-Asia Transport Corridor (TRACECA project). One of the important links of the corridor Europe-Caucasus - Asia is the Black Sea route connecting Ukraine and Georgia. Since 1996, there is an automobile, and since 1999 - the railway ferry Illichivsk (Odesa) - Poti (Batumi), created on the initiative of Ukraine. Following the signing of the trilateral agreement between Georgia, Ukraine, and Bulgaria, a regular train ferry service on the Poti Illichivsk - Varna line was opened. In 2004, the railway ferry service Illichivsk - Derince (Turkey) began to operate. Until 2002, the route TRACECA in Ukraine ended in the port of Illichivsk. In 2001, it was decided to continue the TRACECA in the land territory of Ukraine from Illichivsk to the Yahodyn border point with Poland (with the prospect of entering the Baltic Sea) (Sayt DP "Administratsiya morskykh portiv Ukrayiny").

The development of the ITC and the integration of the national transport system in the European one require the construction of a new network of highspeed railroads. The construction of a new railway network involves a speed of up to $300 \mathrm{~km} / \mathrm{h}$, the use of a fundamentally new rolling stock and a track of $1,435 \mathrm{~mm}$ in width instead of $1520 \mathrm{~mm}$ (Postanova Kabinetu Ministriv Ukrayiny, 2016).

An important role in the ITC system is played by information infrastructure that accumulates, processes, stores, and disposes of information on the availability of cargo, the need for one or other vehicles, provides continuous monitoring of cargo passing, and increases the level of their preservation.

\subsection{Development of transit potential of Ukraine}

Ukraine's conditions are favourable for the development of maritime transport: in the south, there are the Black and Azov seas, which do not freeze and

Table 1

\section{International transport corridors}

\begin{tabular}{|c|c|c|}
\hline $\begin{array}{l}\text { No. } \\
\text { of ITC }\end{array}$ & Route & Countries-participants \\
\hline 1 & $\begin{array}{l}\text { Helsinki - Tallinn - Riga - Kaunas and Klaipèda - Warszawa } \\
\text { and Gdańsk; }\end{array}$ & Finland, Estonia, Latvia, Poland \\
\hline 2 & $\begin{array}{l}\text { Berlin - Poznań - Warszawa - Brest - Minsk - Smolensk - } \\
\text { Moscow - Nizhny Novgorod }\end{array}$ & Germany, Poland, Belarus, Russia \\
\hline 3 & $\begin{array}{l}\text { Brussel - Aachen - Köln - Dresden - Wrocław - Katowice - } \\
\text { Kraków - Lviv - Kyiv; }\end{array}$ & Belgium, Germany, Poland, Ukraine \\
\hline 4 & $\begin{array}{l}\text { Dresden/Nürnberg - Prague - Vienna - Bratislava - Győr - } \\
\text { Budapest - Arad - Bucharest - Constanța/Craiova - Sofia - } \\
\text { Thessaloniki - Plovdiv - Istanbul }\end{array}$ & $\begin{array}{l}\text { Germany, the Czech Republic, Austria, Slovakia, Hungary, } \\
\text { Romania, Bulgaria, Greece, Turkey }\end{array}$ \\
\hline 5 & $\begin{array}{l}\text { Venice - Trieste/Koper - Ljubljana - Maribor - Budapest - } \\
\text { Uzhhorod - Lviv - Kyiv; }\end{array}$ & Italy, Slovenia, Hungary, Ukraine \\
\hline 6 & $\begin{array}{l}\text { Gdańsk - Katowice - Žilina, with a western branch: } \\
\text { Katowice - Brno; }\end{array}$ & Poland, Slovakia \\
\hline 7 & The Danube River (water) & $\begin{array}{l}\text { Austria, Hungary, Yugoslavia, Bulgaria, Romania, Moldova, } \\
\text { Ukraine }\end{array}$ \\
\hline 8 & $\begin{array}{l}\text { Durrës - Tirana - Skopje - Bitola - Sofia - Dimitrovgrad - } \\
\text { Burgas - Varna }\end{array}$ & Albania, Macedonia, Bulgaria \\
\hline 9 & $\begin{array}{l}\text { Helsinki - Vyborg - St. Petersburg - Pskov - Moscow - } \\
\text { Kaliningrad - Kyiv - Liubashivka/Rozdilna - Chișinău - } \\
\text { Bucharest - Dimitrovgrad - Alexandroupoli }\end{array}$ & Finland, Russia, Ukraine, Moldova, Romania, Bulgaria, Greece \\
\hline \multirow[t]{3}{*}{10} & $\begin{array}{l}\text { Salzburg - Ljubljana - Zagreb - Belgrade - Niš - Skopje - } \\
\text { Veles - Thessaloniki }\end{array}$ & Austria, Slovenia, Croatia, Serbia, Macedonia, Greece \\
\hline & Baltic Sea - Black Sea (Gdańsk - Warszawa - Kovel - Odesa) & Poland, Ukraine \\
\hline & Europe - Caucasus - Asia (TRACECA) & $\begin{array}{l}\text { Bulgaria, Romania, Ukraine, Moldova, Georgia, Turkey, Armenia, } \\
\text { Azerbaijan, Kyrgyzstan, Tajikistan, Kazakhstan and Uzbekistan }\end{array}$ \\
\hline
\end{tabular}

Source: formed by the author 
are connected with the Mediterranean Sea via the Bosporus. The sea-economic complex of Ukraine in the Black Sea-Azov basin includes 13 continental seaports with a throughput of 262 million tons per year. The most important seaports are Odesa, Yuzhnyi, Illichivsk, Izmail, Kherson, Mykolaiv, and others, on the banks of the Sea of Azov - Mariupol and Berdiansk. Despite the favourable conditions for the development of maritime transport, according to statistics, it accounts for only $2.4 \%$ of freight turnover and $0.1 \%$ of passenger turnover from the total volume of services provided. In sea transport of goods, the main share is occupied by transportation in foreign (international) connections, which in recent years makes up about 70\% (Sayt DP "Administratsiya morskykh portiv Ukrayiny").

According to the State Statistics Committee, the main types of cargo are metals (24\%), construction materials $(23 \%)$, grain $(11 \%)$, ore $(12 \%)$, oil and petroleum products $(5 \%)$, chemical and mineral fertilizers (3\%), forest materials $(2.5 \%)$, coal, etc. (Sayt DP "Administratsiya morskykh portiv Ukrayiny").

The main problem of maritime transport is the significant obsolescence and physical deterioration of vehicles and port equipment. The average life of trading vessels of Ukraine exceeds 15 years. Therefore, given their technical condition, the vast majority of Western ports prohibit such merchant ships from entering an internal raid. The outdated infrastructure of Ukrainian ports significantly reduces their productivity (up to $50 \%$ of the productivity of the ports of Western countries). The vast majority of merchant fleet vessels are small-tonnage. The average displacement of Ukrainian vessels is 3-5 times less than the similar indicator in such countries as the USA, Japan, Greece, etc. The bulk of the fleet, controlled by domestic ship-owners, is registered in foreign ship registers, which threatens the independence of the transport support of foreign trade of Ukraine.

\section{Results and discussion}

Under the current conditions, for Ukraine, the strategic benchmark for innovative development is the implementation of a technological breakthrough and the creation of a national innovation system that will anticipate the identification of priorities of innovation activity and the formation and implementation of innovative development programs and stimulation of innovation activity.
First of all, the priority directions of innovative activity in the transport system are almost not defined, not substantiated, and weakly interconnected. Therefore, a clearer definition and justification according to the criteria of innovation of priority directions of innovation development of the transport system will enable to form an effective sectoral state innovation policy for activating innovation activity of transport enterprises. By the Resolution № 1056 on 28.12.2016, the Cabinet of Ministers of Ukraine has determined priority innovative directions in the transport sphere for the period of 2017-2021 (Table 2) (Postanova Kabinetu Ministriv Ukrayiny, 2016):

Today, the latest innovations that support the transport industry and improve the service of transport services are:

- electronic freight technology and single-window technology as a factor of acceleration of cargo movement;

- introduction of the electronic document flow of logistics and transport activities (for example, the implementation of projects of electronic submission of information, electronic booking of queues, electronic declaration);

- development and implementation of electronic document circulation standards;

- methods of management and control over transportation costs in order to reduce the cost of delivery of goods by vehicles;

- application of cloud technologies and mobile devices; - management of delivery terms;

- creation of new supply chains/transport corridors and multimodal formats, etc.

In our opinion, the main objective for improving the service of providing transport services is to introduce electronic document flow of logistics and transport activities.

If one analyses the full cycle of delivery of goods, the main time is occupied by operations of preparation of the cargo for transportation and, accordingly, delivery to the client, the term of transportation of goods in most cases takes less time. Therefore, technology and, above all, information technology should be aimed at reducing the time for the preparation and completion of operations related to the development of infrastructure and technology associated with the development of transport vehicles (Voychenko, 2015).

Table 2

Innovative development directions of the transport system

\begin{tabular}{|l|l|l|l|}
\hline \multicolumn{3}{|c|}{ Innovative technologies required in the sphere of transport for the period of 2017-2021 } \\
\hline $\begin{array}{l}\text { Aggregates and systems of the } \\
\text { new generation for speed and } \\
\text { high-speed rail transport }\end{array}$ & $\begin{array}{l}\text { Development and } \\
\text { implementation of intelligent } \\
\text { and digital systems to systems of } \\
\text { transport logistics }\end{array}$ & $\begin{array}{l}\text { New generations of processes } \\
\text { and technology in the aircraft, } \\
\text { ship and space-rocket industry }\end{array}$ & $\begin{array}{l}\text { Development of navigation } \\
\text { systems and control of aviation, } \\
\text { ship and rocket technology }\end{array}$ \\
\hline
\end{tabular}

Source: formed by the author 
The advantage of electronic document flow is that this system allows any links to quickly exchange information with each other. This is the implementation of the principle of "single-window" in transport terminals, where the most labour-intensive processes are associated with the processing of documents - both on arrival of cargo and on shipment. Therefore, it provides an opportunity to accelerate the time to handle a fairly large amount of information, multimodality - the possibility to transfer information from one mode of transport to another and make decisions at the junctions of transport modes.

Also, it is necessary to take into account the important factor involved in the process of cargo execution, except the sender and the recipient, agents (forwarders), carriers, service of transport terminals, and state bodies (customs, phytosanitary control and others, depending on the specifics of the cargo). All this is reflected in a certain number of documents - the invoice, the consignment note, the customs declaration, the export permit, etc. (Voychenko, 2015).

The use of various platforms for electronic document circulation by different actors will not allow the transport system to function effectively; therefore, it is necessary to introduce a system of "single-window" - a common system of electronic document flow for all the agents of the transport market.

To date, the pilot project "Single Window" is used in the activity of the Odesa Sea Commercial Port, the terminals of "TIS" in the territory of the Yuzhnyi Sea Commercial Port, and the Sea Commercial Port of Chornomorsk (Voychenko, 2015).

Let us consider the statistical reporting of ports' work using the Single Window system as of April 2017 (Table 3) (The site of the State Enterprise "Administration of Sea Ports of Ukraine"). Analysing the above data, it can be concluded that during the period since the introduction of the Single Window system, there is a trend of increasing the number of successfully registered containers in the system for their loading. Since the end of 2015, ISPC has been implemented and used in all seaports of Ukraine. In particular, a ship arrival registration module works in all harbours. In Odesa, Black Sea, Yuzhnyi, and Bilhorod-Dnistrovskyi seaports, registration of the ship's arrival takes place exclusively in electronic form. In all other ports - the arrival of the ship is made in parallel mode using the electronic system and in paper form.

In Odesa, the Black Sea port, and the seaport "Yuzhnyi" (for TIS-Container TOV), the ISPC system is used for the import of containerized cargoes imported by the sea mode, the transportation of which is carried out by road and rail transport (Vnedreniye tekhnologiy elektronnoy obrabotki gruzov po tekhnologii IATA e-freightv Ukraine: problemy i perspektivy, 2014).

In addition, the port of Odesa uses an ISPC export module for container and general cargoes and in the
TOV “Black Sea Fishing Port” - a module for export of container cargoes is introduced.

The next step in the development of the ISPC application will be the full transition to the electronic form of ship registration in all ports of Ukraine.

Simplification of trade procedures has become central to Ukraine in the context of integration into European and world markets. Ukraine needs to improve the information security of international trade, one of the main elements of which is the transportation of goods across borders.

Creation of the mentioned system will allow all agents of foreign economic activity - participants of the transport process - to provide information simultaneously, in one single place, in a standard form and to one agency, institution, organization (regardless of the form of ownership).

Today, the UIS is used in the most developed ports, airports, and other intensive border crossing points in the world. In Western Europe, the specified form of single-window functions in ports of Hamburg (Germany), Rotterdam (the Netherlands), Antwerp (Belgium), Felixstowe (Great Britain), Le Havre, Marseille (France), Barcelona, Bilbao (Spain).

On the basis of specified ports, European Port Community Systems Association (EPCSA) was established (Vnedreniye tekhnologiy elektronnoy obrabotki gruzov po tekhnologii ÍATA e-freightv Ukraine: problemy i perspektivy, 2014).

The introduction of the UIS, initially at the local level with the prospect of using this experience to create a national Single Window will bring Ukraine closer to the EU trade development strategy, where a program for developing a network of national mechanisms of Single Window has already adopted that will exchange information on the basis of standards of the UN and World Customs Organization. Thus, at the first stage of the project, the main objective is to implement the above-mentioned UN recommendations, assignments to the Cabinet of Ministers of Ukraine by creating appropriate software and information complexes, means of communication between the participants of the UIS, organizational support of interaction between state and non-state enterprises and institutions on the way of optimization of transport processes, reduction of threats of unpredictable subjective circumstances, cancellation of the human factor's influence on the process of moving goods and vehicles across borders and, consequently, increasing the volume of foreign trade, revenues to the State Budget of Ukraine, taxes and fees. The UIS, which is currently being formed at the Odesa Sea Commercial Port, uses the existing experience and best practices of European ports (Vnedreniye tekhnologiy elektronnoy obrabotki gruzov po tekhnologii ÍATA e-freightv Ukraine: problemy i perspektivy, 2014; The site of the State Enterprise "Administration of Sea Ports of Ukraine"). 


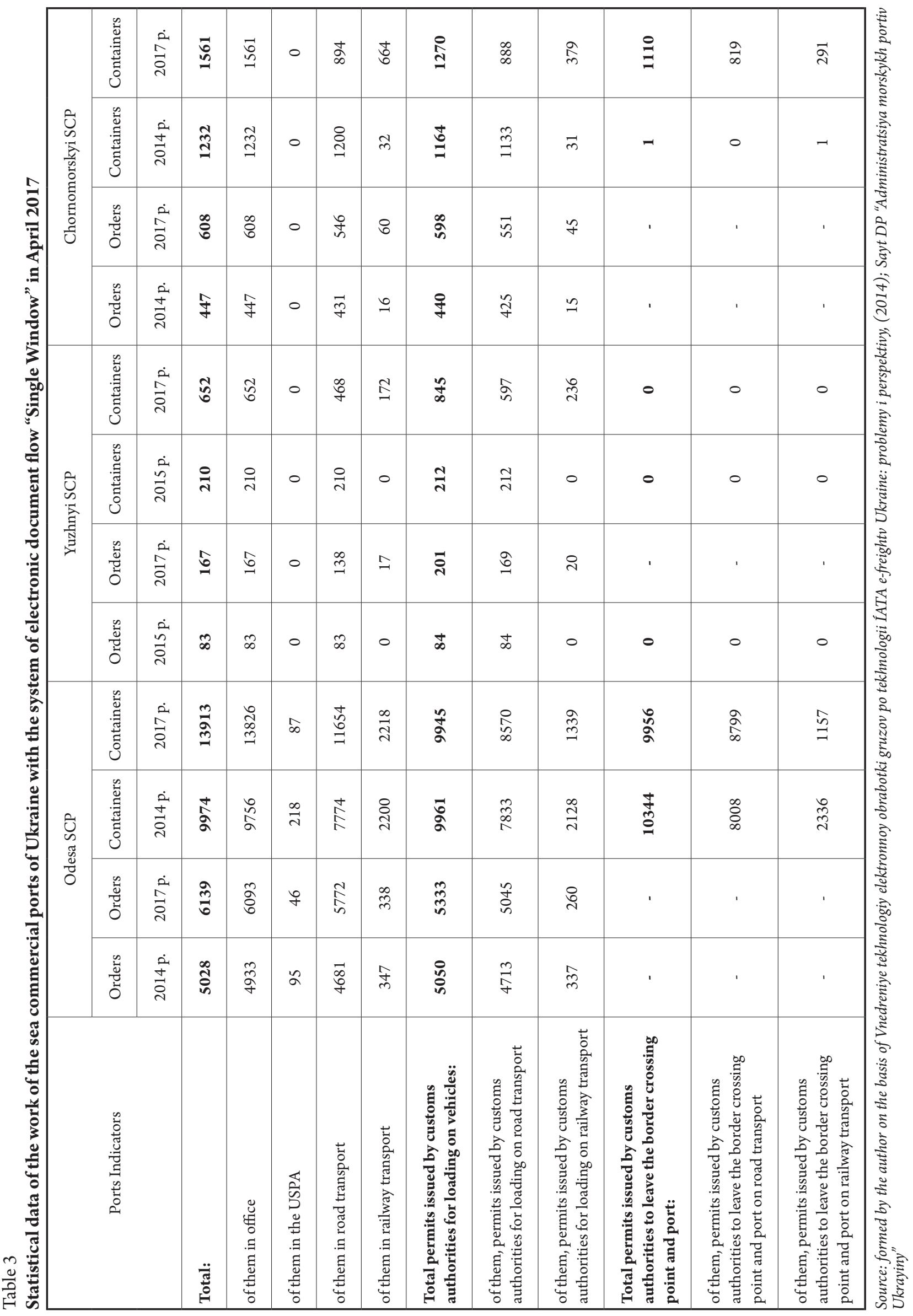


For the development of these structural transformations, we propose to introduce an improved organizational and economic mechanism for regulating innovation activity. The overall structure of the organizational and economic mechanism of innovation activity at a transport enterprise is a complex system of functional links between objects, subjects, means, methods, and other components of innovation activity. Such a system can be used to achieve a wide range of strategic objectives of the enterprise.

In order to determine the conditions for attributing projects and other technical and technological improvements to innovation and investment, and considering that innovation in the field of transport is aimed at creating high-tech products of the highest standards that meet international requirements in order to ensure the implementation of resource and energy saving, environmental and safe technologies, and to improve the quality of transport services, it is necessary to adhere to the criteria of environmental friendliness, safety, quality on the condition of improvement of these parameters by not less than 5\% (Voychenko, 2015).

In relation to this, there is proposed a scheme of improved organizational and economic mechanism for regulating innovation activity of transport enterprises of Ukraine that is shown in Figure 1.

The Law of Ukraine "On Innovation Activity" provides for the creation of central executive authorities in the field of innovation activities of various types of economic activity. They should prepare proposals for the implementation of innovation policy in the relevant economic field, create organizational and economic mechanisms for supporting its implementation (Postanova Kabinetu Ministriv Ukrayiny, 2016). Therefore, it is proposed to improve the organizational structure of the Ministry of Infrastructure of Ukraine by means of creating a separate authority or department.

The proposed structure should have functions related to the state innovation and investment policy in the transport and road complex, which will allow ensuring the effectiveness of the organizational and economic mechanism for regulating the innovation activity of transport enterprises.

\section{Conclusions}

The development of the transport system is impossible without the realization of the transit potential of Ukraine. The introduction of advanced transport technologies aimed at ensuring competitiveness in the market for transport services involves increasing the competitiveness of transportation on the basis of transport logistics.
Creation of modern international transport corridors will allow connecting individual cities or settlements within several countries. For this, it is necessary to introduce innovative technologies for the movement of passengers and cargo. An important role in the ITC system is played by information infrastructure that accumulates, processes, stores, and disposes of information on the availability of cargo, the need for one or other vehicles, provides continuous monitoring of cargo passing, and increases the level of their preservation.

At the state level of Ukraine, the creation of such a system will give a real impetus to the development of a favourable economic and legal space, harmonization of data exchange between various participants in transport business processes and state regulatory bodies, in accordance with the requirements of world standards. In our view, this will be the first step towards the creation of a national single-window format and the associated positive shifts aimed at the European integration, the formation of international supply chains and transfers, the limitation of bureaucratic procedures, and the fight against corruption.

In terms of the transformation of Ukraine's economy, the core of scientific and technological advance is an innovative component aimed at activating mechanisms for the creation of new competitive products and services, the introduction of a new format for business communication, and the formation of new business environment conditions. To ensure the development of the innovative potential of transport companies, we offer the following general proposals:

- to create an effective innovation mechanism in the country, due to constant state support of domestic producers, the attraction of additional financial resources, and constant financial control of independent experts;

- to form a permanent increase in innovation potential based on the introduction of new production technologies, scientific and technical developments that can provide competitive advantages for Ukrainian entrepreneurs in both the domestic and foreign markets in the short term;

- to ensure the provision of transport services and transfers of appropriate quality that correspond to European and international standards.

The source of economic growth can be innovation activity, as of large enterprises of basic industries, as well as of other spheres of the economy, especially transport enterprises and enterprises providing transport services. In order to implement innovations in transport and logistics activities, it is necessary to take into account the experience of the countries of the world, which actively use the latest innovative technologies, and develop unified standards for their effective use. 


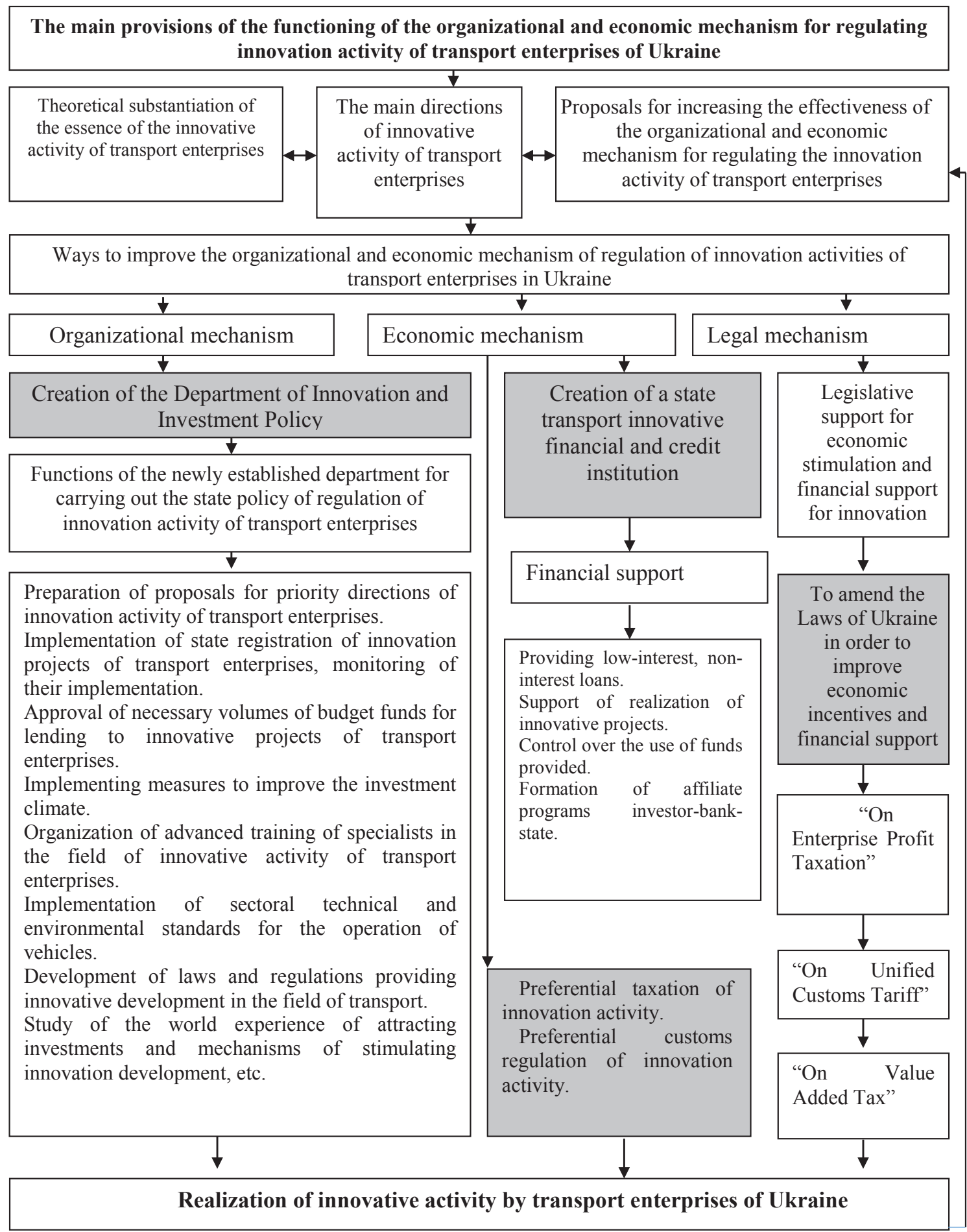

Figure 1. Ways to improve the organizational and economic mechanism for regulating innovation activity of transport enterprises of Ukraine

\section{References:}

Postanova Kabinetu Ministriv Ukrayiny (2016). Deyaki pytannya vyznachennya serednostrokovykh priorytetnykh napryamiv innovatsiynoyi diyalnosti zahalnoderzhavnoho rivnya na 2017-2021 roky [Resolution of the Cabinet of Ministers of Ukraine "Some Issues of Defining Medium-Term Priority Areas of Innovation Activities of the National Level for 2017-2021"]. Retrieved from: http://zakon3.rada.gov.ua/laws/show/1056-2016-\%D0\%BF

Vnedreniye tekhnologiy elektronnoy obrabotki gruzov po tekhnologii ÍATA e-freightv Ukraine: problemy i perspektivy (2014). [Introduction of technologies for electronic cargo handling using IATA e-freight technology in Ukraine: problems and prospects]. 02.04.2014. Vol. 66, № 13, p. 804. 
Voychenko T. (2015). Napryamy innovatsiynoyi diyalnosti u vodno transportniy haluzi [Areas of innovative activity in the water transport industry]. Vol. 31, pp. 142-143.

Prokopenko N.S., Vyklyuk M.I. (2012). Rehulyuvannya innovatsiynoyi diyalnosti pidpryyemstv transportnoho mashynobuduvannya: monohrafiya [Regulation of innovative activity of transport engineering enterprises: monograph]. Lviv: "Liga-press".

Sereda A.R. (2012). Otsinka rivnya vplyvu rehulyuvannya na efektyvnist innovatsiynoyi diyalnosti pidpryyemstv transportnoho mashynobuduvannya AAssessment of the level of regulation influence on the efficiency of innovation activity of enterprises of transport engineering]. Proektuvannya, vyrobnytstvo ta ekspluatatsiya avtotransportnykh zasobiv i poyizdiv: shchorichnyy naukovo-vyrobnychyy zhurnal - Design, production and operation of vehicles and trains: annual scientific and production magazine. Vol. 20, pp. 247-253.

Turpak T.H. (2007). Innovatsiyi yak faktor efektyvnoyi diyalnosti portovoho hospodarstva richkovoho transportu Ukrayiny [Innovations as a Factor for Effective Operation of the Port Economy of River Transport of Ukraine]. Problemy nauky: mizhhaluzevyy naukovo - tekhnichnyy zhurnal - Problems of Science: Interdisciplinary Scientific and Technical Journal. No 8, pp. 33-38.

Materialy konferentsiyi (2013). Innovatsiyi dlya transportu i lohistyky. Materials of the conference "Innovations for transport and logistics". Retrieved from: http://transukraine.com.ua/conference_page_id=125

Pilotnyy proekt «Yedyne vikno - lokalne rishennya» (2014). Statystyka [Pilot project "Single window - local solution". Statistics]. Retrieved from: http://www.singlewindow.org/publications/17? lang=ukr

Sayt DP «Administratsiya morskykh portiv Ukrayiny» [The site of the State Enterprise "Administration of Sea Ports of Ukraine"]. Informatsiynu systemu portovoho spivtovarystva vprovadzheno v usikh morskykh portakh Ukrayiny [Information system of the port community implemented in all seaports of Ukraine]. Retrieved from: http:// www.uspa.gov.ua/pres-tsentr/novini/novini-ampu/11677-informatsionnaya-sistema-portovogo-soobshchestvavnedrena-vo-vsekh-morskikh-portakh-ukrainy 